used definition of a failed operation. When using this definition the results of conventional designs seem so good that it is effectively impossible to show that a new design is significantly better than conventional ones. With current failure rates of around $1 \%$ a year a new design that was a $30 \%$ improvement over an older one (a truly radical improvement) would require a trial of many thousands of patients followed up for at least a decade before a significant difference could be shown. ${ }^{\circ}$ By then the new implant being tested would have disappeared, replaced by a design with even more untried "features." Is there ahy point in continuing the development of new implants if we are using revision as the criteria of failure? The answer is almost certainly no.

To escape the pernicious influence of fashion we need three things. Firstly, we need a national register of hip replacements and revisions to provide an accurate measure of revision rate. This would allow the identification of implants that are doing badly and would allow individual units to compare their performance with national figures. Secondly, we need outcome measures for assessing new implants that are more sensitive to failure than revision. ${ }^{7}$ These would take into account pain and disability at levels that do not currently warrant revision. And, finally, we need ways of assessing early how well an implant is functioning. One of the most promising techniques depends on the very accurate measurement of the sinkage of implants into bone. ${ }^{8}$ Although its predictive value has not been proved, it warrants urgent evaluation. In future such techniques may help to identify design features that improve survival.
Drugs are subjected to rigorous testing before they can be marketed, and the same should be a statutory requirement for implants. Manufacturers would be prepared to foot the bill if testing became law. In its current form the implant industry remains a haven for all the excesses of free enterprise.

C J K BULSTRODE Clinical reader in orthopaedic surgery

D W MURRAY Senior registrar

John Radcliffe Hospital, Oxford OX3 9DU

A J CARR

Nuffield Orthopaedic Centre, Oxford OX3 $7 \mathrm{LD}$

Consultant orthopaedic surgeon

P B PYNSENT

Director of research

$S$ R CARTER

Consultant orthopaedic surgeon

Royal Orthopaedic Hospital,

Birmingham B31 2AP

\footnotetext{
1 How good are knee replacements? Lancet 1991;338:477-8.

2 How to be hip in the 90's. Clinica 1992; 503:14-7.

McCoy TH, Salvati EA, Ranawat CS, Wilson PD. A fifteen year follow-up study of one hundred Charnley low friction arthroplasties. Orhop Clin North Am 1988;19:467-76.

4 Ahnfelt L, Herberts P, Malchua H, Andersson GBJ. Prognosis of total hip replacement. Acta Onhop Scand 1990;61(suppl 238):1-26.

Carter SB, Pynsent PB. What is the true cost of hip arthroplasty. In: Proceedings of the European conference on joint replacement in the 1990s. London: Institute of Mechanical Engineers, 1992.

6 Hip and knee joint replacements. Drug Ther Bull 1992;30:57-60.

7 Murray DW, Bulstrode CB, Carr AJ. Survival analysis and joint replacement. 7 Bone foint Surg (in press).

Freeman MAR. Techniques for the prediction of the long term stability of a prosthetic component. In: The future of orhopaedic implants. London: Institute of Mechanical Engineers, 1991.
}

\title{
Does Crohn's disease have a mycobacterial basis?
}

\section{The case is unproved}

Crohn's disease is an indolent chronic inflammatory disorder that may affect the entire alimentary tract, with inflammation through all layers of the intestine. Its pathogenesis is a mystery. Treatment remains non-specific and consists predominantly of immunosuppression.

The original description by Crohn suggested mycobacteria as a possible cause, given that chronic enteritis in animals, termed Johne's disease, was caused by tubercule bacilli. ${ }^{1}$ The many types of mycobacteria vary in their pathogenicity; some are saprophytic and rarely cause disease, while others are potentially pathogenic, particularly in immunocompromised patients. The pathogenicity of Mycobacteria paratuberculosis remains uncertain.

Research workers have tried for many years to culture mycobacteria from tissue affected by Crohn's disease, although generally without success. ${ }^{2}$ To unravel the complex mycobacteriology of chronic enteritis, investigators have developed sensitive methods to detect and characterise relevant pathogenic strains. Hermon-Taylor's group identified IS900, a DNA repetitive element, in an uncharacterised mycobacterial isolate from a patient with Crohn's disease. This was shown by DNA fingerprinting to be indistinguishable from $M$ paratuberculosis, which causes enteritis in animals. The group suggests that assays based on polymerase chain amplification of highly specific DNA sequences from these insertional elements, and recombinant and synthetic peptides from their predicted proteins, will revolutionise the detection and characterisation of these agents. ${ }^{34}$ These findings should be balanced, however, with a report from another group, which showed that DNA from $M$ paratuberculosis is present not only in Crohn's disease but also in ulcerative colitis and other non-inflammatory bowel disorders. ${ }^{5}$ Furthermore, the mycobacteria detected in Crohn's disease were not identical, suggesting that a single pathogenic mycobacterium does not cause the disease.

Elsaghier and colleagues explored a possible role for $M$ paratuberculosis in the pathogenesis of Crohn's disease. They reported that $57 \%$ of their patients with the disease had antibodies to $M$ paratuberculosis antigens, although only $18 \%$ concurrently had raised titres to three different $M$ paratuberculosis antigens. The authors believed that their serological results supported the view that infection with $M$ paratuberculosis might cause Crohn's disease. ${ }^{6}$ Their failure to include suitable controls with other sinall intestinal disorders or to perform assays for other bacterial antigens, however, makes interpretation of their results difficult. Stainsby and colleagues' finding of no significant difference in serum concentrations of antibodies to various mycobacteria, including $M$ paratuberculosis, between patients with Crohn's disease and ulcerative colitis and healthy controls argues against the hypothesis that Crohn's disease is caused by $M$ paratuberculosis.

The potential role of mycobacteria in the pathogenesis of Crohn's disease has been investigated with monoclonal antibodies to a glycolipid specific to $M$ avium. The antibodies were tested in specimens obtained at bowel resection from patients with Crohn's disease and controls. A positive reaction was seen in the bowel wall, both in patients with Crohn's 
disease and in controls. In controls the positive reaction was limited to the lamina propria, while in Crohn's disease reactivity was also found in the submucosa and subserosa. Although the authors concluded that the results indicated that mycobacteria might have a role in the pathogenesis of Crohn's disease, ${ }^{8}$ a further search for mycobacteria in the affected intestinal tissue with antibodies to $M$ paratuberculosis strain linda, $M$ tuberculosis, and the common mycobacterial antigen lipoarabinomannan failed to find a positive reaction in any of 67 specimens from 30 affected patients. ${ }^{9}$

One case report has described a 38 year old homosexual man who developed fever, diarrhoea, and weight loss and in whom radiography showed terminal ileitis. Microbiological culture of the resected terminal ileum showed numerous $M$ avium intracellulare. Antimycobacterial treatment had previously resulted in weight gain, loss of fever, and resolution of diarrhoea, implying that this patient's terminal ileitis was due to a mycobacterial infection. ${ }^{10}$ Clustering of Crohn's disease in several members of certain families supports the hypothesis of an infective cause. ${ }^{11}$

Antituberculous treatment has been tried in Crohn's disease, although the drugs used have a low sensitivity to atypical mycobacteria including $M$ paratuberculosis. Rifabutin and ethambutol in combination were assessed in 16 patients with recurrent Crohn's disease who had undergone an ileal resection with a partial colectomy and ileocolonic anastomosis. Ten patients were treated for six months; six patients withdrew because of adverse effects. In none of the 10 patients who completed the six months' trial and none of the five patients who completed 12 months' treatment was improvement of the lesions seen on endoscopy. ${ }^{12}$.A pilot study at $\mathrm{St}$ George's Hospital in London has suggested that quadruple treatment with rifampicin, ethambutol, isoniazid, and pyrazinamide or clofazamine may be of value: 10 of 20 patients remained in remission after nine months' treatment. The authors concluded that controlled trials of antimycobacterial treatment, using four or more agents, should be conducted. ${ }^{13}$

Other theories of aetiology continue to be investigated. A group at the Royal Free Hospital in London has implicated a vasculitic process possibly initiated by the measles virus, since encoding mRNA has been found in affected tissue. ${ }^{14}{ }^{15}$ Such agents could initiate an immunological process that becomes self perpetuating long after living organisms have disappeared.

Some cases of granulomatous terminal ileitis are caused by mycobacteria, albeit in immunocompromised people. The presence of antibodies to certain $M$ paratuberculosis proteins in this condition and the finding, with sophisticated polymerase chain reaction techniques, of DNA associated with mycobacterium in the tissue of two thirds of patients with Crohn's disease argues for the involvement of mycobacteria in the pathogenesis of the disease. The failure to find organisms in affected tissue with sensitive immunohistochemical methods and the variable responses of the condition to antituberculous drugs suggest that a definite role for mycobacteria in the pathogenesis of Crohn's disease remains unproved.

PAUL J CICLITIRA

St Thomas's Hospital, Honorary consultant physician

London SE1 7EH

1 Crohn BB, Ginzburg K, Oppenheimer GD. Regional ileilis. A pathological and clinical entity. FAMA 1932;99:1323.

2 Gitnick G, Collins J, Beaman B, Brooks D, Arthur M, Imaeda T, et al. Preliminary report on isolation of mycobacteria from patients with Crohn's disease. Dig Dis Sci 1989;34:925-32.

3 Butcher PD, McFadden JJ, Hermon-Taylor J. Investigation of mycobacteria in Crohn's disease tissue by Southern blotting and DNA hybridisation with cloned mycobacterial genomic DNA probes from a Crohn's disease isolated mycobacteria. Gut 1988;29:1222-8.

4 Sanderson JD, Moss MT, Tizard ML, Hermon-Taylor J. Mycobacterium paratuberculosis DNA in Crohn's disease tissue. Gut 1992;33:890-6.

5 Yoshimura HH, Graham DY, Estes MK, Merkal RS. Investigation of association of mycobacteria with inflammatory bowel disease by nucleic acid hybridisation. F Clin Microbiol 1987;25:45-51

6 Elsaghier A, Prantera C, Moreno C, Ivanyi J. Antibodies to Mycobacterium paratuberculosisspecific antigen in Crohn's disease. Clin Exp Immunol 1992;90:503-8.

7 Stainsby KJ, Lowes JR, Allan RN, Ibbotson JP. Antibodies to Mycobacterium paratuberculosis and nine species of environmental mycobacteria in Crohn's disease and control subjects. Gut 1993;34:371-4.

8 Kobayashi K, Blaser MJ, Brown WR. Immunohistochemical examination for mycobacteria in intestinal tissue from patients with Crohn's disease. Gastroenterology 1989;96:1009-15.

9 Blaauwgeers JL, Das PK, Slob AW, Houthoff HJ. Human gut wall reactivity to monoclonal antibodies against $\mathrm{M}$ avium glycolipid in relation to Crohn's disease (preliminary results). Acto Leprol 1989;7:138-40.

10 Schneebaum CV, Novick DM, Chabon AB, Strutynsky N, Yancovitz SR, Freund S. Terminal ileitis associated with Mycobacteria avium intracellular infection in a homosexual man with acquired immune deficiency syndrome. Gastroenterology 1987;92:1127-32.

11 Rutgeerts P, Geboes K, Vantrappen G, Van Isveldt J, Peeters M, Penninckx F, et al. Rifabutin and ethambutol do not help recurrent Crohn's disease in the neoterminal ileum. $f$ Clin Gastroenterol 1992;15:24-8

12 Hampson SJ, Parker MC, Saverymuttu SH, Joseph AE, McFadden JJ, Hermon-Taylor J. Quadruple antimycobacterial chemotherapy in Crohn's disease: results at 9 months of a pilo study in 20 patients. Alimentary Pharmacology and Therapeutics 1989;3:343-52.

13 Wakefield AJ, Sankey EA, Dillon AD, Sawyer AM, More L, Sun R, et al. Granulomatous vasculitis in Crohn's disease. Gastroenterology 1991;100:1279-87.

14 Wakefield AJ, Sim R, Cosby L, Dhillon AP, Issertte M, Taylor M, et al. Detection of measles virus genomic RNA in Crohn's disease by in situ hybridisation. Gut 1992;33:S2.

15 Van Kruiningen HJ, Colombel JF, Cartun RW, Whitlock RH, Koopmans M, Kangro HO, et al. An in-depth study of Crohn's disease in two French families. Gastroenterology 1992;103:351-60.

\section{Night visits in general practice}

\section{An acceleration, with the new contract, of an underlying rising trend}

A steep rise in claims for night visits followed the introduction of the general practitioner contract in 1990 (p 762), ${ }^{1}$ mostly resulting from the one hour extension to each end of the period of eligibility (2300-0700 hours). The underlying rising trend that existed before the introduction of the contract was, however, maintained. Deputising services undertook relatively fewer visits in $1990-1$ - at $28 \%$, the proportion was down from $46 \%$ in $1989-90$, the last year of the old contract. Although the overall number of night visits increased sharply in the first year after the introduction of the contract (for example, in Berkshire it rose by a half over the previous year (p 762)), the absolute number of night visits made by the deputising service may have altered much less, without much cost saving.

The extended hours of eligibility and the greater rewards for general practitioners who make their own night visits readily explain these changes in activity. Whether the proportion of night calls dealt with by telephone advice fell as a result of the greater financial incentive to visit is unknown.

Why there is an underlying rising trend in night visiting, especially when average list sizes have fallen steadily, ${ }^{2}$ is less easily explained. In part, it reflects the secular increase in overall consultation rates ${ }^{3}$ due to sociodemographic changes such as the increase in numbers and proportions of elderly people and the very young. ${ }^{4}$ Rates of out of hours calls for these age groups, as for general practitioner consultation rates in general, are higher, and relatively more calls from elderly patients result in home visits. ${ }^{5}$ Also, the proportion of households containing one person living alone increased between 1981 and 1991 from $22 \%$ to $26 \%$, and the proportion of households containing only one adult and at least one child increased from $2 \%$ to $4 \%{ }^{4}$ In these often lonely circumstances 